\title{
Information studies for the business sector in Spanish universities
}

\author{
Antonio Muñoz Cañavate ${ }^{\mathrm{a}}$ and Pedro Hípola ${ }^{\mathrm{b}}$ \\ ${ }^{a}$ Departamento de Información y Comunicación, Facultad de Biblioteconomía y Documentación, \\ Universidad de Extremadura, Spain \\ E-mail: amunoz@alcazaba.unex.es \\ ${ }^{\mathrm{b}}$ Departamento de Biblioteconomía y Documentación, Facultad de Comunicación y Documentación, \\ Universidad de Granada, Spain \\ E-mail: phipola@ugr.es
}

Received 18 December 2007

The management of information in the business world constitutes a single consolidated area within undergraduate and graduate study programs in Librarianship and Information Science. This article describes information studies for the business sector within Spain, including the university programs known as Diplomatura in Librarianship and Documentation (equivalent to a three-year first cycle in Library and Information Science), and Licenciatura in Documentation (a two-year second cycle). It also presents the contradictions that are found between the professional implications of the information society paradigm, on the one hand, and the academic strategies of the discipline in Spain, which are largely trapped in a traditional framework.

\section{Introduction}

Since the introduction of higher-level studies in Librarianship and Documentation (the preferred term in Spain for "Information Science") in Spanish Universities in the 1980's, advances in these areas have been significant. Yet Spain has not escaped the tension in the relationships between the academic and professional spheres, or in academic development per se within the university setting. The current scenario might be described as one of uneasiness on the part of professionals in libraries and archives (which were staffed, previous to the appearance of specialized university studies, by people without specific university qualifications); and a commonly encountered reticence in the universities, whose graduates may be fearful of competition in the limited employment field (the gap between professionals and academics remains, albeit less intensively with the more widespread introduction of university graduates into information centers countrywide).

This is not the only arena of conflict, however, as there are also tensions within the Spanish university system itself, between Library Science and Information Science, a problem not exclusive to Spain, and well documented by Cronin in the nineties [1]. We find, then, teachers who work toward integration, so that under the umbrella of Information Science or Documentation are included libraries, archives and information centers in diverse institutions; whereas others use a terminology that is specific 
only to libraries and archives in order to underline the difference that they consider well justified. Furthermore, in recent years Spain has seen an attempt to establish a separate identity for the archival studies, its advocates arguing that they are underrepresented in current documentation study programs. Some archival associations have gone even further and expressed their disagreement with the notion that archives is a professional field lying within Information Science or Documentation.

The broth in which these problems simmer might be traced to faculty members in those universities that have not been able to broaden their horizons and "rethink" the discipline, in that they continue to speak of libraries, archives or documentation centers, when the universalization of access to information has made it evident that, at present, organizations no longer have information systems and/or services in some parts of their organization that function autonomously; information is now recognized as a strategic resource that must be managed in the organization as a whole. Nomenclature also has contributed to the controversy. Moscoso has suggested it is necessary to banish certain classic titles that cubbyhole the profession by confusing the part with the whole, and that terms such as librarian, archivist or documentalist should be replaced by "information manager" [2].

In light of this change in scenery, it is desirable that universities themselves be aware of the official data on levels of employment associated with LIS studies. Table 1 shows the results of a study by the Spanish Ministry of Labour, presenting job positions in Spain occupied by degree-holders in Librarianship and Documentation in 2003. It is disappointing, even alarming, to see how many university graduates were employed as porters or delivery persons, shop assistants, bookkeepers, or workers in the manufacturing or food industries, positions that do not call for a university education.

Perhaps the academic debate, with its strong implications for the labor market (as we see in Table 1) should bear in mind the profile of the professors of librarianship and information science in Spain. When university LIS schools were established in Spain, they mostly hired professors who were already teaching in the university, for instance in the humanities, or else worked in libraries and archives. This situation conditioned LIS teaching and research for many years, though in the early nineties, with the reformed study plan (a three-year first cycle program of Diplomatura in Librarianship and Documentation, and the appearance of a two-year second cycle Licenciatura in Documentation, both resulting from the Law on University Reform of 1983), a timid change could be glimpsed. This academic reform allowed professors of statistics, computer science, law or business studies to be hired, thereby complementing the more traditional subjects and improving Spanish university studies. In turn, the new classes of students produced professors with a broader view of LIS studies and the related professions. Further development came in the nineties, with the establishment of a doctoral program. This reform also allowed compulsory subjects within Documentation to be taught by other Spanish university degree-holders, such as graduates of Translation and Interpretation, Audiovisual Communication and Public Administration. 
Table 1

Occupation for which degree-holders in Documentation in Spain were hired

\begin{tabular}{|c|c|c|c|c|}
\hline & \multicolumn{2}{|c|}{ Diplomados } & \multicolumn{2}{|c|}{ Licenciados } \\
\hline & $\mathrm{N}^{\circ}$ contracts & $\begin{array}{l}\mathrm{N}^{\circ} \text { persons } \\
\text { contracted }\end{array}$ & $\begin{array}{c}\mathrm{N}^{\circ} \\
\text { contracts }\end{array}$ & $\begin{array}{r}\mathrm{N}^{\circ} \text { persons } \\
\text { contracted }\end{array}$ \\
\hline Administrative assistant & 644 & 521 & 150 & 128 \\
\hline Librarian & 342 & 274 & 80 & 67 \\
\hline Documentalist & 204 & 183 & 138 & 120 \\
\hline Commercial/shop assistant & 150 & 134 & 21 & 20 \\
\hline Library assistant & 128 & 94 & 42 & 32 \\
\hline Worker in manufacturing industry & 101 & 80 & 15 & 15 \\
\hline Interviewer, pollster & 62 & 18 & 43 & 8 \\
\hline Porter/mover/delivery person & 61 & 45 & - & - \\
\hline Worker in food industry & 52 & 16 & - & - \\
\hline Archiver & - & - & 20 & 19 \\
\hline Job trainer & - & - & 14 & 13 \\
\hline
\end{tabular}

Source: Informe del mercado de trabajo de las titulaciones universitarias delárea de Ciencias sociales y jurídicas. Madrid: Ministerio de Trabajo, 2003. p. 17 and 141.

Table 2

Number of students registered in LIS Diplomatura (Spain's three-year program)

\begin{tabular}{lccccccc}
\hline & $1999 /$ & $2000 /$ & $2001 /$ & $2002 /$ & $2003 /$ & $2004 /$ & $2005 /$ \\
& 2000 & 2001 & 2002 & 2003 & 2004 & 2005 & 2006 \\
\hline Librarianship and & 4.874 & 4.675 & 4.777 & 4.419 & 3.998 & 3.429 & 2.901 \\
$\begin{array}{l}\text { Documentation students } \\
\begin{array}{l}\text { Variation (\%) with respect } \\
\text { to previous academic year }\end{array}\end{array}$ & -4.08 & 2.18 & -7.49 & -9.53 & -14.23 & -15.40 \\
\hline
\end{tabular}

Source: INE (Spanish National Statistics Institute), 2007.

Table 3

Number of students registered in LIS Licenciatura (Spain's two-year second cycle program)

\begin{tabular}{lllllllc}
\hline & $1999 /$ & $2000 /$ & $2001 /$ & $2002 /$ & $2003 /$ & $2004 /$ & $2005 /$ \\
& 2000 & 2001 & 2002 & 2003 & 2004 & 2005 & 2006 \\
\hline Documentation students & 2.606 & 3.218 & 3.732 & 3.839 & 3.717 & 3.525 & 3.139 \\
Variation \%) with respect & & 23.48 & 15.97 & 2.87 & -3.18 & -5.17 & -10.95 \\
to previous academic year & & & & & & & \\
\hline
\end{tabular}

Source: INE, 2007.

Nevertheless, in Spain the number of students registered for studies in librarianship and documentation has dropped sharply (Tables 2 and 3). Aside from the effects of the very low birth rate seen in Spain in the seventies and eighties, a cause often evoked in meetings by those responsible for degree studies in librarianship and information science, today's society does not understand the role and the function of students graduating from these disciplines.

Many professors feel that in the Spanish university setting, librarianship and information science have lost their allure; they have not adapted to the new opportunities arising with the current Information Society and Knowledge Society, or the changing reality and corresponding new possibilities for employment. The aforementioned 
separation is accentuated by the fact that many teachers, in speaking of their particular world, highlight the boundaries between libraries, archives and documentation centers. If we take as an analogy the field of medicine, and despite the great complexity of the human body, wouldn't it be irritating to see medicine as an educational program split into factions depending on the part of the body that a doctor specializes in, with each specialist vindicating its own identity regardless of neighboring interests?

What we need to transmit is a realization that the management of informational resources should be widened to include a multitude of public and private entities, and that information systems must no longer be localized and controlled in one part of the organization, but rather extended to the organization as a whole. In the words of Olaisen [3] "the growing awareness that information behaves as an active economic resource like capital, plant or human resources has focussed on how to manage information as a strategic resource". Meanwhile, Burk and Horton [4] express the nature of Information Resource Management thus: "IRM refers to the application of traditional management processes, particularly resource management principles, to the stewardship of an organization's information resources and assets".

It has become clear since the introduction of information and communication technologies into all sorts of organizations, that in the post-industrial society, in a society of information and knowledge, new work arenas that did not exist previously have emerged, altering professional frontiers. As Buckland and Liu argue [5], Information Science should be seen from a broader perspective when undertaking the curricular design of Information Science programs at the university leve:. "IS is centered on the representation, storage, transmission, selection (retrieval, filtering), and the use of documents and messages, where documents and messages are created for use by humans".

In the broad field of information resource management, the management of information for the needs of businesses should constitute an important subject within the academic discipline of Information Science just because firms, in any country, greatly outnumber libraries or historical archives. Furthermore, the recent growth in the overall context of managing company information has given rise to specific disciplines such as Competitive Intelligence (the identification, retrieval, analysis and management of external information that affects the operations, decisions and plans of a given enterprise).

This understanding has oriented initiatives in a number of countries, including, for example, France. In 2001 the Association des professionels de l'information et de la documentation (ADBS) had already published, at the forefront of the CERTIDOC project, the Référentiel des métiers-types des professionnels de l'information et de la documentation, which established a catalog of 19 professions within the entrepreneurial setting. This report complements Euro-referencial en Información y Documentación in defining the competencies of European information and documentation professionals. In September of 2006, seven French organisations established yet another list of occupations and competencies in the realm of Economic Intelligence: Assemblée des Chambres Françaises de Commerce et d'Industrie 
(ACFCI); Association des professionnels de l'information et de la documentation (ADBS); Agencia Nacional de Empleo (ANPE); Fédération des Professionnels de l'Intelligence Economique (FEPIE); Haut responsable en charge de l'intelligence économique (HRIE); Institut Français de l'Intelligence Economique (IFIE); Association Française pour la Promotion de l'Intelligence Economique et Concurrentielle (SCIP France).

If we assume that information acts as an intangible, fundamental ingredient of economic development, and is a resource that must be managed well, the effort invested in processing information in the company setting serves to eliminate uncertainties in organizational movement, and to make available the data that the organization itself generates and manages.

There is, indisputably, a substantial labor market for professional specialists in information management for business activities. Studies by Marcella and Baxter [6] carried out in the nineties at the Robert Gordon University School of Information and Media spotted an emerging market for information professionals in sectors such as the supply and analysis of financial and political information; the study by Tabah and Bernhard [7] at the School of Library and Information Science of the University of Montreal underlined the rise of technological vigilance as another field of activity; and studies by Quarmby, Willet and Wood involving Information Management graduates from Sheffield conclude that the degree holders obtained employment, above all, in industrial and commercial sectors [8].

Yet in Spain, to date, there is no close correlation between professional experience in the business world and the profile of graduates in Information Science. In 1996 Jiménez López and González Quesada [9] described the difficulties encountered by Librarianship and Documentation graduates in getting hired as documentalists in sectors as specialized as chemistry or the pharmaceutical industry: those responsible for hiring in these sectors prefer science graduates. Another source of ballast may be the attitude of degree holders who, instead of adapting to a company's needs, expect the firm to somehow adjust to their background, skills and interests. In 1998, at the VII Jornadas de la EUByD of the Universidad Complutense in Madrid, some participants spoke out as to why, in their opinion, the documentalist had not solidified in the business realm: on the one hand, the documentalist is more concerned with internal processes than in contributing to competitive advantages in the marketplace; on the other hand, the LIS professional has only limited concerns as to the tangible and intangible benefits of his or her work [10]. Similarly, in a seminar given by the (former) FID in Granada (southern Spain) in 1994, Karl Kalseth [11], president of the FID/II Committee (Information for Industry), elaborated on how the skills of the librarian do not satisfy the needs of a business, since companies and executives need persons able to manage information fluently in order to achieve "improved knowledge".

The need for information management in the business world goes beyond the processing of a documentary collection. The complexity of the setting of any single business generates uncertainties that must be eliminated prior to the formulation 
of decisions or policy. The company as an organization is surrounded by diverse spheres whose outlines and outlets must be defined or controlled. And if we want the management of information in the company to control external information fluxes, the process of management cannot be limited solely to managing the document collection of the organization. It must also guarantee that those responsible for it become active vigilantes, providing reliable data and information for the different levels of management.

In the case of Spanish business enterprises, we might ask whether they are sufficiently aware of the significance underlying the management of business information. A study carried out by Muñoz in 2005 focused on the companies with the greatest invoice turnover and largest staffs in the Spanish region of Extremadura [12]. The findings regarding their uses of information and knowledge management corroborate the scarcity of information management specialists. For instance, when asked "Does your company have a unit of information and/or documentation?" only $27.40 \%$ of the firms responded yes, $69.86 \%$ said no, and $2.74 \%$ gave no answer. And to the query "Do you have responsible personnel dedicated to the management of information, with exclusive dedication or without exclusive dedication?" $45 \%$ answered that yes they did have someone without exclusive dedication, but just $3 \%$ affirmed the exclusivity of task dedication. With respect to knowledge of the setting (environmental scanning), however, there would seem to be some variance in large businesses: when asked if the firm has a structural mechanism (department or person) in charge of obtaining external information for the decision-making process, the affirmative response was as high as $46.58 \%$. This figure is similar to the result of the study by Tena Millan and Comai [13] involving multinational firms based in Catalonia, where $45.7 \%$ of the firms surveyed responded yes to the same question.

\subsection{The structure of the Diplomatura and Licenciatura programs in Spain, and European Reform}

Before addressing the current state of studies in Business Information in Spain, within the context of Information Science studies, we need to provide some background about the origins of these studies in Spain.

Formal university studies in Librarianship and Documentation began in Spain in the eighties, as mentioned earlier, with the publication of the Royal Decree 3104/1978 and a Ministerial Order in February of 1981 that laid down directives for these study plans in Spain's University system. We ought to point out, though, that in Spain there were relevant developments much earlier, in the mid-19 ${ }^{\text {th }}$ century, and that in one way or another these were continued throughout the $20^{\text {th }}$ century, until the appearance of the official university study program. In the mid-19th century, the Escuela de Diplomática was created (though it disappeared in 1900), its objective being to train librarians and archivists. In 1915 the Escuela de Bibliotecarias de Barcelona was created (the seed of which would decades later become the Escuela de Biblioteconomía y Documentación de la Universidad de Barcelona). In 1947 the 
Escuela de Formación Técnica de Archivos, Bibliotecas y Museos was founded, the direct antecedent of the Escuela de Documentalistas de Madrid, itself founded in 1964. In 1977, with the creation of the Ministerio de Cultura y la Direcci ón General del Libro y Bibliotecas, it changed its name to Escuela de Bibliotecarios, and in 1980 to Centro de Estudios Bibliográficos y Documentarios; only to finally disappear in 1986, when the first university schools of Library Science began to appear.

It is therefore in the context of the legal directives established in 1978 and 1981 that undergraduate degree studies leading to a Diplomatura in Librarianship and Documentation (three years of study) were established in 1983 in three different Spanish centers: Barcelona, Granada and Salamanca. In the time that elapsed between the initial introduction of these studies and their development, a process of university reform was taking place in Spain. The Law of University Reform of 1983 created a new point of departure for teaching in the bulk of the Spanish university system. The plan of studies for the Diplomatura was modified through two decrees (Real Decreto 1497/1987 on common general directives, and the Real Decreto 1422/1991 regarding the Diplomado en Biblioteconom ía y Documentación). After this turning point, new LIS schools would be created all over Spain. Shortly after the first few graduating classes emerged, studies leading to a Licenciatura degree (an additional two years) in Documentation were established through Real Decreto 912/1992. Whereas the Diplomatura was meant to form technicians, the Licenciatura was intended to prepare directors and managers.

At present, in Spanish universities both the Diplomatura and the Licenciatura programs can be followed. Some centers impart both degree programs, and others only one of the two. All the study plans feature a core of subjects (common to all centers throughout the country) along with compulsory subjects and optives established by each individual center. There is, moreover, a fourth type of subject "subjects of free election" - consisting of material that is basically open to students from different schools or academic backgrounds who are working toward a free or individualized configuration of their studies; this material may not surpass $10 \%$ of the student's total credit load.

At the time of writing, Spanish universities are immersed in a process of adaptation to the European Space for Higher Education (ESHE), which will re-structure the totality of the programs. ESHE aspires to create a flexible system with degrees of comparable academic depth that will allow for student mobility within Europe and elsewhere. In Spain, this process is underway, gradually replacing the current university structure. Higher education will, in future, revolve around one of three structural cycles:

1. First cycle. Undergraduate degrees (replacing the diplomaturas, licenciaturas and engineering degrees) that comprise the basic education or general formation. In Spain, the Diplomatura in Librarianship and Documentation and the Licenciatura in Documentation will be fused into a degree to be called "Graduate in Information and Documentation". 
2. Second cycle. Postgraduate studies, to include a Master's degree in advanced studies, as well as multidisciplinary and advanced study programs.

3. Third cycle. Doctorate level. This embraces the doctoral program, with the focus on research, to conclude with the $\mathrm{PhD}$ dissertation and degree.

This process of adaptation or upheaval is ongoing, and although certain components are still evolving, in Spain the undergraduate degrees will require 240 credits, as opposed to 180 credits constituting the first cycles of other European countries.

\subsection{Business Information Management as a subject in the different academic cycles of Documentation studies in Spain}

Our methodological approach is based on the following three realms:

1. The teaching of information management for the business world, as imparted in current first and second cycles (Diplomatura and Licenciatura);

2. The introduction of firms as practical stages for learning, in which the student may carry out internal information management tasks in the context of the "Practicum" within the Diplomatura in any of the Spanish universities; and

3. Recognition of graduate programs, both in terms of their courses and the lines of research established.

This study presents information pertaining to the academic year 2006/07.

To highlight the place of business information knowledge in current first and second cycle (Diplomatura and Licenciatura programs), we extracted only those subjects that are explicitly related to the management of information in this busines organizations. Excluded, then, were those subjects of a general character regarding information sources, even though they might have some syllabus content related to business functions. Likewise excluded were subjects about information sources in science and technology, or sources in the social sciences. With respect to the management of internal information, also excluded were subjects addressing archival duties, although some mention might be made of archives within a company setting. We also eliminated subjects dedicated to the management of knowledge if they did not expressly refer to business knowledge management, as the management of knowledge may apply to any type of organization. The results for the Diplomatura in Librarianship and the Licenciatura in Documentation are presented in Tables 4 and 5 respectively.

In the case of the Diplomatura in Librarianship and Documentation in Spain, the 12 universities offering these programs, four have no content specifically on information management in the business setting, whether related to internally generated information or external information sources. Of the remaining eight, with a total of nine pertinent subjects, five pertain to information (one of them a compulsory subject, and the others electives), and the rest present different aspects of the processing of internal information. In other words, $67 \%$ of the universities offer this type of subject, 
Table 4

Diplomatura in Librarianship and Documentation

\begin{tabular}{lllc}
\hline University & Subject & & Credits \\
\hline A Coruña & $\begin{array}{l}\text { Documentación Administrativa y de } \\
\text { empresas }\end{array}$ & Obligatory & 6 \\
Barcelona & Información en la empresa & Optive & 6 \\
Carlos III de Madrid & La información para la industria & Obligatory & 7 \\
Complutense de Madrid & Archivística Especial II (Científica y de & Optive & 4,5 \\
& Empresa) & Optive but not of- & 4,5 \\
& Información para la Empresa & fered in 2006/07 & 6 \\
Extremadura & Servicios de Información para la & Optive & 8 \\
Granada & Empresa & Optive & \\
León & Gestión de información en la empresa & & 5 \\
Murcia & None & Optive & \\
Salamanca & Documentación Empresarial & & 6 \\
Valencia Estudi General & None & None & Fuentes de información especializada en \\
Vic & Fonomía y empresa & & \\
Zaragoza & None & & \\
\hline
\end{tabular}

Source: the authors.

Table 5

Licenciado in Documentation

\begin{tabular}{lllc}
\hline University & Subject & & Credits \\
\hline A Coruña & Fuentes de Información en Economía & Obligatory & 6 \\
& y Empresa & & \\
Alcalá de Henares & None & & \\
Autónoma de Barcelona & None & Optive & 6 \\
Barcelona & Fuentes de información económica y & & 6 \\
Carlos III de Madrid & Archivos de empresa & Optive & \\
Complutense de Madrid & None & & \\
Extremadura & None & & 4.5 \\
Granada & None & Virtual optive & \\
Murcia & Sistemas de Información en la Empresa & Optive & 4.5 \\
Oberta de Catalunya & Fuentes de información en economía y & Optive & \\
& empresa & & \\
Politécnica de Valencia & Inteligencia Competitiva & & \\
Salamanca & None & & \\
\hline
\end{tabular}

Source: the authors.

yet surprisingly, the vast majority are electives. A closer look at the content of the compulsory courses reveals the low importance of business information management in the overall framework of Diplomaturas in Spain.

In the case of the Licenciatura degree in Documentation, only seven of the 12 universities that offer these studies have some business-oriented subject in information management. That is, not even $50 \%$ provide material about the management 
of resources for information specifically in the business setting. And of these, just one university - A Coruña - includes information sources as a compulsory subject; the remaining five offer only electives, two of them with a focus on sources, one on archives, one on competitive intelligence, and one on information systems in the business area.

Meanwhile, with the Practicum now obligatory in all the Diplomaturas programs in LIS nationwide, attempts are being made to extend students' exposure to professional realities. In our case, the Practicum permitted us to explore the bond that exists between the academic and the professional worlds. The practicum locations were obtained from the web pages of the universities in some cases, and in others were supplied by persons at the university in charge of the practicum.

While it is not possible to determine all the tasks undertaken by students in the Practicum, some conclusions can be drawn. First, only very few practicum sites do not involve strictly librarianship or archival tasks. The practicum sites in the mass media offer the best exceptios to this norm, although the tasks undertaken may be only in the documentation category. So, what is the story with the other companies? There are no tasks related to information technology. Business settings as practicum sites are practically inexistent, and when available they tend to offer practice geared toward the management of their own libraries, although some universities also offer practicums in business organizations (just one case), in chambers of commerce (one case) or centers of entrepreneurial research and renovation (four cases).

Finally, what is the situation in Spain as far as the current graduate and postgraduate programs are concerned? Out of the universities that provide such (whether first or second cycle) in Librarianship and Information Science, 16 maintain graduate programs as of 2007. Yet only six have courses or lines of research in the field of competitive intelligence, technological vigilance, entrepreneurial innovation, or the use of specific information resources such as patents (in the case of just one university). These findings, unimpressive as they may be, afford a glimpse into the presence of subjects in the graduate cycles: there is a timid yet growing interest regarding these subject areas in the university context.

\section{Conclusions}

With this paper we have attempted to describe the situation of "Information management for the business enterprise" in the different academic cycles within the curricular structure of Librarianship and Information Science in Spain. Our results reveal a very poor panorama in a realm that we hold to be of great strategic relevance. The situation of these studies in Spain further suffers from the decreasing number of students registering for Documentation studies, and with truly precarious employment possibilities. The fact that many graduates end up doing jobs that have nothing to do with their university preparation urges us to provide crucial feedback to the curricular designers and other key figures who are responsible for giving direction to such academic channels and their outlets, in a fluent and collective process of making decisions and searching for solutions. 


\section{References}

[1] B. Cronin, Cutting the gordian knot, Information Processing \& Management 31(6) (1995), 897-902.

[2] P. Moscoso, La gestión de recursos informativos en el marco de la Sociedad de la Información, Documentación de las Ciencias de la Información 21 (1998), 78.

[3] J. Olaisen, Information versus information technology as a strategic resource, International Journal of Information Management 10(3) (1999), 192-214.

[4] C.F. Burk and F.W. Horton. Infomap: A Complete Guide to Discovering Corporate Information Resources, Englewood Cliffs, NJ, Prentice Hall, 1998.

[5] M.K. Buckland and Z. Liu, History of Information Science, Annual Review of Information Science and Technology 30 (1995), 385-416.

[6] R. Marcella and G.A. Baxter. Career progression survey of graduates of the Postgraduate Diplo$\mathrm{ma} / \mathrm{MSc}$ in information analysis, Education for Information 16 (1998), 107-130.

[7] A.N. Tabah and P. Bernhard. Emplois occupés après la diplomation et champs d'activité perçus comme importants "aujourd'hui" et "dans cinq ans" selon l'enquête menée auprès des diplomes de l'Ebsi (1991-1995), Argus 27(2) (1998), 5-13.

[8] C. Tejada Artigas and J.A. Moreiro. Mercado de trabajo en Biblioteconomía y Documentación. Estudios sobre la inserción laboral de los titulados universitarios, El Profesional de la Informacín 12(1) (2003), 4-9.

[9] M.A. Jiménez López and A. González Quesada, Dificultades de inserción laboral del bibliotecariodocumentalista en el sector de la empresa privada: el caso de las industrias qúmica y farmacéutica. In: V Jornadas, Españolas de Documentación Automatizada, Cáceres (1991), 103-110.

[10] M.T. Fernández Bajón, La profesión de documentalista: apuntes para una reflexión, Boletín de la ANABAD 49(2) (1998), 295-307.

[11] A. Muñoz-Cañavate, Seminario de la FID en Granada. British Airways invierte el equivalente a dos aviones Jumbo en adquirir información, Information World en español (21 February), (1994), 16.

[12] A. Muñoz-Cañavate. Un estudio sobre la gestión de la información y del conocimiento en empresas de una región española. Consideraciones sobre la importancia del profesional de la informacón y la documentación en el mundo empresarial, in: VII Encuentro de EDIBCIC. Marilia (Sao Paulo) Brasil, November, 2006, pp. 606-619.

[13] J. Tena Millan and A. Comai, La Inteligencia Competitiva en las Multinacionales Catalanas, Barcelona: Emecon Consultores, 2004. 